Радчук, 2015 - Радчук Г. К. Психолого-педагогічні засади впровадження освітнього діалогу у навчальний процес викладачами ВНЗ. Проблеми гуманітарних наук: Збірник наукових прачь Дрогобищького держсвного педагогічного університету імені Івана Франка. Серія «Психологія». Дрогобич : Видавничий відділ ДДПУ імені Івана Франка, 2015. Випуск тридцять п'ятий. С. 85-101.

Старовойтенко, 2006 - Старовойтенко О. Б. Проблема суб'єкта в культурній психології особистості. Людина. Суб'єкт. Вчинок: Філософсько-психологічні студії / за заг. ред. В. О. Татенка. Київ, Либідь, 2006. С. 230-257.

\title{
REFERENCES
}

Vyhotskyi, 2003 - Vyhotskyi L. S. Psykholohyia razvytyia cheloveka. Moskva : «Smysl», «Eksmo», 2003. $1136 \mathrm{~s}$.

Dubovytskaia, 2005 - Dubovytskaia T. D. Metodyka dyahnostyky sytuatyvnoi samoaktualyzatsyy lychnosty: kontekstnyi podkhod. Psykholohycheskyi zhurnal. 2005. № 5. S. 70-78.

Koul, 1997 - Koul M. Kulturno-istorycheskaia psykholohyia: Nauka budushcheho / per. s anhl. Moskva : Kohyto-Tsentr, 1997. 432 s.

Mamardashvyly, 1992 - Mamardashvyly M. K. Kak ya ponymaiu fylosofyiu. Moskva : Kultura, 1992. $365 \mathrm{~s}$.

Radchuk, 2015 - Radchuk H. K. Psykholoho-pedahohichni zasady vprovadzhennia osvitnoho dialohu u navchalnyi protses vykladachamy VNZ. Problemy humanitarnykh nauk: Zbirnyk naukovykh prats Drohobytskoho derzhavnoho pedahohichnoho universytetu imeni Ivana Franka. Seriia «Psykholohiia». Drohobych : Vydavnychyi viddil DDPU imeni Ivana Franka, 2015. Vypusk trydtsiat piatyi. S. 85-101.

Starovoitenko, 2006 - Starovoitenko O. B. Problema subiekta v kulturnii psykholohii osobystosti. Liudyna. Subiekt. Vchynok: Filosofsko-psykholohichni studii / za zah. red. V. O. Tatenka. Kyiv: Lybid, 2006. S. 230-257.

\section{Ольга Склянська,} заступник директора КСЗНРЗ «Дніпропетровський обласний методичний ресурсний иентр» ДОР; аспірант відділу інклюзивного навчання Інституту спеціальної педагогіки і психологіі імені Миколи Ярмаченка НАПН Украӥни.
Olha Sklianska, Deputy Director in PSSERI «Dnipropetrovsk Regional Methodical Resource Center» DRC; postgraduate in Department of Inclusive Education of Mykola Yarmachenko Institute of Special Pedagogy and Psychology of NAES of Ukraine.

E-mail: olga.sklianska@gmail.com

ORCID: 0000-0003-3159-8765

\section{ПСИХОЛОГО-ПЕДАГОГІЧНИЙ СУПРОВІД ДИТИНИ РАННЬОГО ВІКУ 3 ОСОБЛИВИМИ ПОТРЕБАМИ В УМОВАХ ІНКЛЮЗИВНО- РЕСУРСНОГО ЦЕНТРУ}

\footnotetext{
Розглянуто моделі психолого-педагогічної допомоги дітям раннього віку та раннього втручання. Здійснено порівняння основних принципів та характеристик програм ранньої психолого-педагогічної допомоги та раннього втручання. Визначено провідні аспекти психологопедагогічної допомоги дітям раннього віку з позицій біопсихосоиіальної моделі інвалідності.
} 
Виділено завдання та спрямованість психолого-педагогічної допомоги дітям з особливими потребами, що забезпечується інклюзивно-ресурсним иентром. Здійснено спробу визначити структуру психолого-педагогічного супроводу дітей раннього віку з особливими потребами в умовах інклюзивно-ресурсного центру. Розглянуто основні етапи підготовки дитини раннього віку з особливими потребами до інклюзивного навчання в дошкільному закладі: розвиток дитини з особливими потребами та підготовка до включення в освітнє середовище; комплексна психолого-педагогічна оцінка розвитку дитини та розробка рекомендації щзодо освітньої програми, корекційно-розвиткової роботи та необхідни пристосувань середовища; супровід інклюзивного навчання дитини з особливими потребами в закладі освіти. Окреслено провідні аспекти функціонального підходу до оцінки розвитку дитини раннього віку. Виділено принщипи психолого-педагогічного супроводу з огляду на біопсихосочіальну модель розуміння інвалідності, щзо враховує взаємодію біологічних, психологічних та соціальних факторів розвитку дитини. Наведено апробовані методики вивчення стану психічних функиій та діяльності дитини як окремого індивіда, різних аспектів батьківства та особливостей сочіальної взаємодї дитини раннього віку з дорослим. Окреслено ключові аспекти складання та реалізачї індивідуальної програми розвитку дитини раннього віку.

Ключові слова: біопсихосоціальна модель інвалідності, дитина раннього віку, дитина з особливими потребами, інклюзивно-ресурсний центр, психолого-педагогічний супровід.

Actuality of research is based on processes of reformation of state system of special needs education in Ukraine and providing psychological and pedagogical assistance for an early age children with special needs. The models of early assistance services and early intervention services are compared. Author distinguishes significant differences at the goal, characteristic of relationship between parents and specialists, factors of effectiveness of two models of early assistance services and early intervention services. The issue although distinguishes the main tasks of psychological and pedagogical maintenance and correction for special needs children in inclusive resource center by the Order of the KMU «On Approval of the Regulations on the Inclusive Resource Center». Maine aspects of psychological and pedagogical maintenance in conception of bio-psyche-social model of disability are defined. The issue consist significant aspects of the functional approach for the evaluation of early age child development and principles of psychological and pedagogical assistance in order to International Classification of Functioning, Disability and Health for children and teenagers. Author suggest to made an evaluation of child development using the domains from chapter Activities and Participation in International Classification of Functioning, Disability and Health for children and teenagers. The two qualifiers for the Activities and Participation component are the performance qualifier and the capacity qualifier. The issue presents an attempt to definite structure and stages psychological and pedagogical assistance for an early age children with special needs in inclusive resource center. The stages of psychological and pedagogical maintenance for preparation children with special needs for inclusive education are described. Author cites a link to methods for evaluation of mental functions of early age child, for research relationship and interaction parents with early age child. The issue although presents the main aspects of individual program of child development elaborating.

Keywords: bio-psyche-social model of disability, early age children, children with special needs, inclusive resource center, psychological and pedagogical assistance.

Постановка проблеми. Важливість раннього виявлення та допомоги у випадку труднощів в розвитку дитини наразі не викликає сумнівів. Досвід перших років життя надзвичайно важливий для формування пізнавальної, емоційно-вольової сфер та особистості дитини (Л. Божович, . Галігузова, Т. Срмолова, М. Лісіна, С. Мєщєрякова, Ю. Разєнкова, О. Смірнова, С. Сорокіна). Чисельні нейрофізіологічні дослідження виявили високу пластичність нервової системи дитини в ранньому віці, тобто здатність до структурної та функціональної перебудови в ході розвитку та дозрівання, що стає підгрунтям для значних 


\section{Psychology}
компенсаторних
можливостей
(С. Джуан,
Н. Дойдж,
Є. Гусєв,
П. Камчатнов).

Під впливом результатів наукових досліджень в Україні протягом останніх десятиліть активно розвивалися послуги ранньої реабілітації та ранньої психолого-педагогічної допомоги, які створені в рамках медичної моделі розуміння інвалідності. Перехід до біопсихосоціальної моделі розуміння інвалідності вимагає орієнтації на ідеї нормалізації життя дитини $з$ інвалідністю та їі родини і максимального, наскільки дозволяють можливості дитини, залучення до життя родини й громади. Це означає також залучення дитини з особливими потребами до системи освіти.

У сучасній системі освіти України завдання забезпечення права дітей 3 особливими потребами, в тому числі раннього віку, на освіту забезпечують інклюзивно-ресурсні центри. Положенням про інклюзивноресурсний центр, затвердженим Постановою Кабінету міністрів України № 545 від 12.07.2017 p., передбачено надання допомоги дітям 3 особливими потребами від двох років. Саме на ці установи покладено завдання супроводу інклюзивного навчання дітей з особливими потребами, зокрема з раннього віку. Отже, розробка моделі психолого-педагогічного супроводу дітей 3 особливими потребами раннього віку в умовах інклюзивно-ресурсного центру наразі є актуальною.

Аналіз останніх досліджень. Система психолого-педагогічної допомоги, спрямованої на допомогу дітям перших трьох років життя 3 відхиленням або загрозою відставання у психомоторному та соціальноемоційному розвитку дитини розглянута в роботах М. Малофєєва, Ю. Разєнкової, Н. Урядницької та ін. Грунтовний аналіз основних принципів психолого-педагогічної моделі допомоги дітям раннього віку представлений в роботах Г. Кукурузи, С. Миронової [Кукуруза, 2013: c. 168-172; Миронова, 2011: c. 70]. Досвід ранньої психолого-педагогічної допомоги в закладах освіти України представлений в публікаціях С. Васильковської, Г. Кукурузи, В. Ремажевської та ін. Загальні принципи раннього втручання, як комплексної послуги для дітей раннього віку 3 порушеннями розвитку та ризиком їх виникнення, розглянуті в роботах Р. Мухамедрахімова, П. Жиянової. Останні дослідження в галузі раннього втручання присвячені розробці рутинно-орієнтованого підходу (R. McWiliams) та навчанню дитини в природних умовах (C. Dunst).

Названі вище дослідження проблеми психолого-педагогічної допомоги дітям раннього віку 3 особливими потребами потребують адаптації до сучасних організаційних умов та нормативних рамок роботи інклюзивно-ресурсних центрів.

Mema cmammi - проаналізувати публікації щодо досвіду запровадження в Україні моделі психолого-педагогічної допомоги дітям раннього віку з особливими потребами та їхнім родинам і запропонувати модель психолого-педагогічного супроводу дитини раннього віку в умовах інклюзивно-ресурного центру. 
Виклад основного матеріалу. Розглянемо детальніше головні завдання та принципи психолого-педагогічної моделі ранньої допомоги дітям 3 проблемами в розвитку та модель раннього втручання.

Психолого-педагогічна модель ранньої допомоги дітям 3 проблемами в розвитку базується на положеннях культурно-історичної теорії Л. Виготського, також спирається на роботи М. Лісіної, О. Стребєлєвої, Ю. Разєнкової, Л. Шипіциної. Головною метою ранньої допомоги $є$ ефективне подолання, корекція та компенсація відхилень у дитини 3 перших місяців життя. Головною умовою ранньої корекційної допомоги в цій моделі виступає єдність психолого-медико-педагогічної діагностики та комплексної допомоги. До найважливіших принципів відносяться: урахування сензитивних періодів розвитку, залучення сім’і, загальний характер психолого-педагогічного супроводу, реалізація ранньої корекційної допомоги в ігровій діяльності, міждисциплінарна взаємодія [Миронова, 2011: с. 70].

Раннє втручання - це система комплексної міждисциплінарної сімейно-центрованої допомоги дітям від народження до 4 років із порушеннями здоров'я та розвитку, спрямована на розвиток дитини, нормалізацію життя родини, профілактику інвалідизації та попередження інституалізації дітей [Кукуруза, 2013: c. 168-172]. Послуга раннього втручання націлена на психологічну та інформаційну підтримку родини дитини $з$ особливими потребами, розвиток функцій дитини (психічних i фізичних) та облаштування середовища, що підтримали б самостійність дитини та їі участь у житті родини і громади. Сучасна практика раннього втручання базується на біопсихосоціальній моделі інвалідності, завдяки чому програми вирішують не тільки окремі проблеми дитини, але й питання якості життя родини і питання соціалізації дитини та родини. Головними принципами раннього втручання є сімейно-центрований підхід, командна робота фахівців (Р. Мухамедрахімов, П. Жиянова), а також функціональний підхід до оцінки стану дитини (Г. Кукуруза). Варто зазначити, що ідея наближення навчальних завдань та методів корекційної роботи до щоденного практичного досвіду дитини була сформульована Л. Виготським i не $\epsilon$ новою для українських практиків. Наукове осмислення досвіду адаптації моделі раннього втручання до умов України висвітлено в роботах А. Кравцової, Г. Кукурузи, О. Романчука.

Порівняння основних принципів і характеристик програм ранньої психолого-педагогічної допомоги та раннього вручання представлені в табл. 1.

Розглянемо основні завдання та напрямки роботи інклюзивноресурсного центру, визначені Положенням про інклюзивно-ресурсний центр. До завдань інклюзивно-ресурсного центру відносяться зокрема такі:

«1) проведення комплексної оцінки з метою визначення особливих освітніх потреб дитини..., розроблення рекомендацій щодо освітньої 


\section{Psychology}

програми, надання психолого-педагогічних та корекційно-розвиткових послуг відповідно до потенційних можливостей дитини;

2) надання психолого-педагогічних та корекційно-розвиткових послуг дітям з особливими освітніми потребами, які навчаються у закладах дошкільної, загальної середньої, професійної (професійно-технічної) освіти та інших закладах освіти, які забезпечують здобуття загальної середньої освіти (не відвідують заклади освіти) та не отримують відповідної допомоги;

3) участь педагогічних працівників інклюзивно-ресурсного центру в командах психолого-педагогічного супроводу дитини 3 особливими освітніми потребами у закладах загальної середньої та дошкільної освіти, а також психолого-педагогічних комісіях спеціальних закладів загальної середньої освіти з метою моніторингу динаміки розвитку дитини не рідше, ніж двічі на рік...» [Постанова КМУ..., 2017].

Основні принципи та характеристики програм ранньої

Табличя 1 психолого-педагогічної допомоги та раннього втручання

\begin{tabular}{|c|c|c|}
\hline & $\begin{array}{c}\text { Психолого-педагогічна } \\
\text { допомога }\end{array}$ & Раннс втручання \\
\hline $\begin{array}{l}\text { Отримувач } \\
\text { послуг }\end{array}$ & $\begin{array}{lr}\text { Дитина } 3 \text { відхиленням або } \\
\text { загрозою відставання } \\
\text { психомоторному } \\
\text { соціально-емоційному } \\
\text { розвитку }\end{array}$ & $\begin{array}{l}\text { Родина, що виховує дитину із } \\
\text { порушеннями в розвитку або } 3 \\
\text { ризиком їх виникнення }\end{array}$ \\
\hline Головна мета & $\begin{array}{l}\text { Ефективне подолання, } \\
\text { корекція та компенсація } \\
\text { відхилень у дитини }\end{array}$ & $\begin{array}{l}\text { Попередження інвалідизації, } \\
\text { нормалізація життя дитини та } \\
\text { родини }\end{array}$ \\
\hline $\begin{array}{l}\text { Основні } \\
\text { принципи }\end{array}$ & $\begin{array}{l}\text { 1. Урахування сензитивних } \\
\text { періодів розвитку. } \\
\text { 2. Залучення сім’ї. } \\
\text { 3. Загальний характер } \\
\text { психолого-педагогічного } \\
\text { супроводу. } \\
\text { 4. Реалізація ранньої } \\
\text { корекційної допомоги в } \\
\text { ігровій діяльності. } \\
\text { 5. Міждисциплінарна } \\
\text { взаємодія. }\end{array}$ & $\begin{array}{l}\text { 1.Сімейно-центрований } \\
\text { підхід. } \\
\text { 2.Міждисциплінарна } \\
\text { командна. } \\
\text { 3.Функціональний підхід до } \\
\text { оцінки розвитку дитини. } \\
\text { 4.Навчання дитини } \\
\text { природних умовах. } \\
\text { 5.Доступність послуги. }\end{array}$ \\
\hline $\begin{array}{l}\text { Стосунки між } \\
\text { фахівцями та } \\
\text { батьками } \\
\end{array}$ & Вертикальні & Горизонтальні \\
\hline Форми роботи & $\begin{array}{l}\text { Індивідуальні та групові } \\
\text { заняття } 33 \text { дітьми, } \\
\text { консультації батьків }\end{array}$ & $\begin{array}{l}\text { Заняття команди фахівців } 3 \\
\text { родиною (дитина }+ \text { батьки), } \\
\text { домашні візити, групи } \\
\text { батьківської самопідтримки }\end{array}$ \\
\hline
\end{tabular}




\begin{tabular}{|l|l|l|}
\hline Умови & Сдність психолого-медико- & -Партнерство з батьками \\
ефективності & педагогічної діагностики & -Оптимізація середовища, в \\
& та комплексної допомоги & якому розвивається дитина \\
& -Робота, спрямована на \\
& оптимізацію стосунків \\
& батьків (опікунів) та дитини \\
& & -Доказовий підхід до вибору \\
& & методів \\
\hline
\end{tabular}

Положення про інклюзивно-ресурсний центр визначає психологопедагогічний супровід наступним чином: «Психолого-педагогічний супровід - це комплексна система заходів з організації освітнього процесу та розвитку дитини, передбачена індивідуальною програмою розвитку» (п. 38) [Постанова КМУ..., 2017].

Концепція супроводу як професійної діяльності передбачає комплекс заходів, спрямованих на оптимізацію та підтримку реалізації особою актуальних завдань і проходження нормативних етапів розвитку. Отже, з огляду на вікові етапи розвитку дитини раннього віку та відповідно до норм Положення, ми можемо визначити наступні етапи психологопедагогічної допомоги дитині раннього віку з особливими потребами:

1) Розвиток дитини 3 особливими потребами та підготовка до включення в освітнє середовище;

2) Комплексна психолого-педагогічна оцінка розвитку дитини та розробка рекомендації щодо освітньої програми, корекційно-розвиткової роботи та необхідних пристосувань середовища;

3) Супровід інклюзивного навчання дитини 3 особливими потребами в закладі освіти.

Розглянемо детальніше перший 3 визначених етапів психологопедагогічного супроводу дитини раннього віку з особливими потребами. Розвиток дитини з ООП та іï підготовка до подальшого включення в освітнє середовище включає:

- Встановлення робочого альянсу з родиною;

- Оцінку функціонування дитини та іiі родини, вивчення факторів зовнішнього середовища, що сприяють або ускладнюють розвиток дитини;

• Визначення завдань корекційно-розвиткової роботи та складання індивідуальної програми розвитку;

- Реалізація індивідуальної програми розвитку.

Як зазначають В. Кобильченко, А. Обухівська, Р. Овчарова, мета супроводу - створити в рамках того середовища, в якому живе дитина, умови для ऑii максимального особистісного розвитку та навчання [Кобильченко, 2009; Психолого-педагогічний..., 2015]. Для дитини раннього віку таким об'єктивно даним середовищем є її родина та той дорослий, що безпосередньо виховує малюка. Отже, важливим завданням супроводу постає оптимізація взаємин у системі «батьки-дитина». Необхідну інформацію про актуальні особливості взаємодії в кожній конкретній 


\section{Psychology}

родині та фактори, що впливають на формування взаємодії і мають бути враховані в подальшій роботі, надає психологічне вивчення. Методами вивчення виступають бесіда, опитування та структуроване спостереження.

Оиінку функиіонування дитини здійснюе команда фахівців, спираючись на структуру Міжнародної класифікації функціонування обмеження життєдіяльності та здоров'я дітей і підлітків. Цей документ охоплює весь комплекс життєдіяльності дитини та дозволяє вивчити й описати біологічні, психологічні соціальні фактори розвитку дитини:

- Структури організму: анатомічні частини організму, такі як органи, кінцівки та їхні компоненти;

- Функції організму: фізіологічні функції систем організму (включаючи психічні процеси);

- Активність - це можливість виконання завдання або дії особою; діяльність;

-Участь - це залучення особи у життєву ситуацію/суспільну

- Фактори навколишнього середовища формують фізичне, соціальне середовище та середовище стосунків і настанов, де люди живуть і проводять свій час.

Можливість виконання завдань (активність) та використання умінь у життєвих ситуаціях (участь) вивчається в дев'яти життєвих сферах (доменах) та складає матрицю даних, представлену в табл. 2 [MКФ..., 2007].

Таблиия 2

Активність та Участь: інформаційна матриця

\begin{tabular}{|c|l|c|c|}
\hline \multicolumn{2}{|c|}{ Домени } & \multicolumn{2}{c|}{ Кваліфікатори } \\
\hline & \multicolumn{1}{|c|}{$\begin{array}{c}\text { Реалізація } \\
\text { (виконання) }\end{array}$} & Здатність \\
\hline d1 & Навчання та застосування знань & & \\
\hline d2 & Загальні завдання та вимоги & & \\
\hline d3 & Комунікація & & \\
\hline d4 & Мобільність & & \\
\hline d5 & Самообслуговування & & \\
\hline d6 & Участь у повсякденному житті & & \\
\hline d7 & $\begin{array}{l}\text { Міжособистісні взаємодії та } \\
\text { стосунки }\end{array}$ & & \\
\hline d8 & Основні сфери життя & & \\
\hline d9 & $\begin{array}{l}\text { Спільнота, соціальне та } \\
\text { громадянське життя }\end{array}$ & & \\
\hline
\end{tabular}

Кваліфікатор «Виконання» описує те, що дитина робить у ii поточному середовищі, використовує в побуті або життєвих ситуаціях. Кваліфікатор «Здатність» описує здатність дитини виконувати завдання чи 
дію в так званому «стандартизованому» середовищі, тобто в ситуації тестування. «Розрив між здатністю та виконанням відображає різницю між впливом існуючих та уніфікованих середовищ $\mathrm{i}$, таким чином, забезпечує корисне керівництво щодо того, що може бути зроблено для навколишнього середовища людини для поліпшення виконання» [МКФ..., 2007].

Методики вивчення стану психічних функцій та діяльності дитини як окремого індивіда, що контактує з предметним світом або з дорослим, розроблені та апробовані (Л. Аксьонова, О. Лісєєв, Н. Тюріна, Г. Пантюхіна, К. Печора, Е. Фрухт, О. Стрєбєлєва, Ю. Разєнкова, О. Смірнова, Л. Галігузова, Т. Срмолова, С. Мєщєрякова та ін.). Також розроблені та досить добре відомі методики вивчення різних аспектів батьківства: емоційне ставлення до дитини (О.Захарова), структура батьківських ставлень (О. Смірнова, М. Бикова, А. Варга, В. Столін), стилі сімейного виховання (Е. Ейдеміллер, В. Юстіцкіс). Для цих завдань використовуються опитувальники та проективні методики, зокрема «Твір про мою дитину», «Незакінчені речення», «Малюнок родини».

Для дослідження процесів взаємодії близького дорослого та дитини все більш популярними $є$ метод структурованого спостереження та аналізу відеозаписів, як то «The Parent-Child Early Relation Assessment» (R. Clark), «Parenting Interactions with Children: Checklist of Observations Linked to Outcomes» (PICCOLO ${ }^{\mathrm{TM}}$ ), інтерактивна методика аналізу відеозаписів взаємодії матері з немовлям О. Ісеніної, методика вивчення відеозаписів взаємодії матері і дитини у вільній грі М. Ланцбург [Склянська, 2018: c. 230].

Як відмічає Г. Кукуруза, важливим є також 3'ясування саме батьківського погляду на моторний, сенсорний, комунікативний, соціально-емоційний розвиток дитини; отримання інформації про особливості організації розвивального простору в домашніх умовах. Від батьків фахівці отримують інформацію про психологічний та соціальний анамнез, фактори зовнішнього середовища, що впливали на розвиток дитини, які стреси на думку батьків могли б вплинути або впливають на розвиток дитини [Кукуруза, 2013: c. 185-186]. Обговорення результатів оцінки з батьками $\epsilon$ важливим етапом психолого-педагогічного супроводу родини, який дозволяє формувати партнерські стосунки фахівців 3 батьками, дозволяє підвищити інформованість батьків про стан дитини та перейти до наступного етапу розробки індивідуальної програми розвитку.

Індивідуальна програма розвитку дитини раннього віку складається міждисциплінарною командою фахівців та є документом, що відображає планування комплексу заходів 3 психолого-педагогічної допомоги та корекційно-розвиткової роботи. Напрям заходів психолого-педагогічного супроводу, що відображається в індивідуальній програмі розвитку визначений п. 39 Положення про інклюзивно-ресурсний центр: 


\section{Psychology}

«Психолого-педагогічний супровід, психолого-педагогічні та корекційнорозвиткові послуги спрямовані на:

- соціалізацію дітей з особливими освітніми потребами, розвиток їх самостійності та відповідних компетенцій;

- формування компенсаційних способів діяльності як важливої умови підготовки дітей з особливими освітніми потребами до навчання в закладах дошкільної... освіти;

- розвиток навичок саморегуляції та саморозвитку дітей 3 урахуванням наявних знань, умінь і навичок комунікативної діяльності, становлення особистості» [Постанова КМУ..., 2017].

Індивідуальна програма розвитку дитини раннього віку, окрім загальних відомостей про дитину та ії родину, має містити: cфepax;

- відомості про активність та участь дитини в основних життєвих

- інформацію про індивідуальні особливості та інтереси дитини, які мають бути враховані при встановленні контакту та залученні дитини до діяльності;

- інформацію про фактори зовнішнього середовища, які допомагають або ускладнюють формування необхідних компетентностей та самостійності дитини, в тому числі характер дитячо-батьківських стосунків;

- узгоджений запит, що визначає загальний напрямок роботи та довгострокову мету;

• конкретні завдання корекційно-розвиткової роботи з формування необхідних умінь дитини та оптимізації фізичного середовища, а також завдання психологічного супроводу батьків;

- графік проведення занять та консультацій фахівцями;

- планування моніторингу.

Реалізація індивідуальної програми розвитку дитини раннього віку передбачає надання психолого-педагогічних та корекційно-розвиткових послуг у формі індивідуальних та групових занять за обов'язковою участю батьків (опікунів) дитини, психологічне та інформаційне консультування батьків (опікунів), домашні візити 3 метою вивчення та оптимізації середовища розвитку дитини (С. Васильковська, Г. Кукуруза) [Психологопедагогічний..., 2015; Кукуруза, 2013].

Добір методів корекційно-розвиткової роботи має відповідати завданням психолого-педагогічного супроводу, визначеним індивідуальною програмою розвитку, індивідуальним можливостям i вподобанням дитини та спиратися на відомості про дослідження ефективності тих чи інших методик і технологій.

Висновки. Аналіз представлених моделей допомоги дітям раннього віку із порушеннями в розвитку виявив наступні принципи, що відповідають специфічним особливостям психологічної сутності феномена немовляти: центрованість на родині та стосунках з близьким дорослим, 
рутинно-орієнтований підхід. Виявлені також принципи, що відповідають соціальній моделі інвалідності: функціональний підхід до оцінки розвитку дитини, оптимізація середовища, в якому розвивається дитина. Також виділені спільні характеристики психолого-педагогічної допомоги та раннього втручання, що відповідають головним завданням психологопедагогічного супроводу дитини 3 особливими потребами в рамках інклюзивно-ресурсного центру: комплексна та системна допомога, робота міждисциплінарної команди.

Подальшого дослідження та розробки потребують проблеми комплексної психолого-педагогічної оцінки розвитку дитини раннього віку 3 позицій біо-психо-соціальної моделі інвалідності, апробація методик корекційно-розвиткової роботи 3 дітьми раннього віку 3 особливими потребами та технології методичного супроводу інклюзивного навчання дітей з особливими потребами в закладах дошкільної освіти.

\section{ЛІТЕРАТУРА}

Кобильченко, 2009 - Кобильченко В. В., Вавіна Л. С., Глущенко К. О. Психолого-педагогічний супровід дітей з порушеннями зору та слуху. Київ : Науковий світ, 2009. 168 с.

Кукуруза, 2013 - Кукуруза Г. В. Психологічна модель раннього втручання: допомога сім'ям, що виховують дітей раннього віку з порушеннями розвитку: монографія. Харків : Планетапрінт, 2013. 244 с.

Миронова, 2011 - Миронова С. Педагогічна допомога дитині раннього віку з особливостями психофізичного розвитку. Вихователь-методист дошкільного закладу. 2011. № 5. C. $67-72$.

МКФ, 2007 - Міжнародна класифікація функціонування, обмеження життєдіяльності та здоров'я: діти та підлітки (версія): МКФ-ДП [Електронний ресурс]. Всесвітня організація охорони здоров'я. 2007. Режим доступу : http://moz.gov.ua/mkf.

Постанова КМУ, 2017 - Постанова КМУ № 545 від 12.07.2017 «Про затвердження Положення про інклюзивно-ресурсний центр» [Електронний ресурс]. Режим доступу : http://zakon.rada.gov.ua/laws/show/545-2017-\%D0\%BF.

Психолого-педагогічний, 2015 - Психолого-педагогічний супровід сім’ї у роботі психологомедико-педагогічної консультації: [електронний ресурс] / авт. кол.: С. І. Васильковська, Т. В. Жук, Т. Д. Ілляшенко та ін. ; за ред. А. Г. Обухівської. Київ : Український НМЦ практичної психології і соціальної роботи, 2015. С. 47-52.

Склянська, 2018 - Склянська О. В. Вивчення та корекція взаємодії батьків із дитиною раннього віку з порушеннями психофізичного розвитку за допомогою аналізу відеозаписів. Науковий вісник Херсонського державного університету. Серія «Психологічні науки». 2018. № 2. C. 229-233.

\section{REFERENCES}

Kobylchenko, 2009 - Kobylchenko V. V., Vavina L. S., Hlushchenko K. O. Psykholoho-pedahohichnyi suprovid ditei z porushenniamy zoru ta slukhu. K. : Naukovyi svit, 2009. $168 \mathrm{~s}$.

Kukuruza, 2013 - Kukuruza H. V. Psykholohichna model rannoho vtruchannia: dopomoha simiam, shcho vykhovuiut ditei rannoho viku z porushenniamy rozvytku: monohrafiia. Kharkiv : Planeta-print, 2013. 244 s.

Myronova, 2011 - Myronova S. Pedahohichna dopomoha dytyni rannoho viku z osoblyvostiamy psykhofizychnoho rozvytku. Vykhovatel-metodyst doshkilnoho zakladu. 2011. № 5. S. 67-72.

$M K F, 2007$ - Mizhnarodna klasyfikatsiia funktsionuvannia, obmezhennia zhyttiediialnosti ta zdorovia: dity ta pidlitky (versiia): MKF-DP [Elektronnyi resurs]. Vsesvitnia orhanizatsiia okhorony zdorovia. 2007. Rezhym dostupu : http://moz.gov.ua/mkf. 


\section{Psychology}

Postanova KMU, 2017 - Postanova KMU №545 vid 12.07.2017 «Pro zatverdzhennia Polozhennia pro inkliuzyvno-resursnyi tsentr» [Elektronnyi resurs]. Rezhym dostupu : http://zakon.rada.gov.ua/laws/show/545-2017-\%D0\%BF.

Psykholoho-pedahohichnyi, 2015 - Psykholoho-pedahohichnyi suprovid simi u roboti psykholohomedyko-pedahohichnoi konsultatsii: [elektronnyi resurs] / avt. kol.: S. I. Vasylkovska, T. V. Zhuk, T. D. Illiashenko ta in. ; za red. A. H. Obukhivskoi. K. : Ukrainskyi NMTs praktychnoi psykholohii i sotsialnoi roboty, 2015. S. 47-52.

Sklianska, 2018 - Sklianska O. V. Vyvchennia ta korektsiia vzaiemodii batkiv iz dytynoiu rannoho viku z porushenniamy psykhofizychnoho rozvytku za dopomohoiu analizu videozapysiv. Naukovyi visnyk Khersonskoho derzhavnoho universytetu. Seriia «Psykholohichni nauky». 2018. № 2. S. 229-233.

\author{
Олеся Столярчук, \\ доктор психологічних наук, \\ доиент кафедри \\ психологї̈ особистості \\ та соиіальних практик \\ Київського університету \\ імені Бориса Грінченка.
}

Olesia Stoliarchuk, Doctor of Psychology, Associate Professor of the Department of Psychology of Personality and Social Practices of Borys Grinchenko Kiev University.

E-mail: o.stoliarchuk@kubg.edu.ua

ORCID 0000-0003-4252-2352

\section{Оксана Сергєєнкова,} доктор психологічних наук, професор, завідувач кафедри психології особистості та сочіальних практик Київського університету імені Бориса Грінченка.
Oksana Serhieienkova, Doctor of Psychology, Heard of Psychology of Psychology of Personality and Social Practices of Borys Grinchenko Kiev University.

E-mail: o.serhieienkova@kubg.edu.ua

ORCID 0000-0002-1380-7773

\section{ФОРМУВАННЯ ПСИХОЛОГІЧНОЇ ГОТОВНОСТІ СТУДЕНТІВ ДО МАЙБУТНЬОЇ ПРОФЕСІЙНОЇ ДІЯЛЬНОСТІ}

У роботі розкрито зміст, функиї та складові компоненти поняття психологічної готовності студента до фахової діяльності як індикатора успішності його професіоналізації. Запропоновано розиирене тлумачення психологічної готовності особистості студента до фахової діяльності як загальної спрямованості на професійну діяльність у річищі життєвої самореалізачії. Унаслідок проведення пілотного емпіричного дослідження виявлено розповсюдженість складнощів і суперечностей особистісного становлення майбутніх фахівців на етапі їхньої професійної підготовки, щуо зумовило доречність розроблення й апробації програми гармонізаиії становлення особистості майбутнього фахівця. Програму реалізовано в річищі трьох змістових векторів - індивідуалізації, професіоналізації й універсалізації. Одним із провідних індикаторів успішності реалізації програми визнано психологічну готовність студентів до майбутньої професійної діяльності. Проаналізовано результати реалізації програми гармонізачї становлення особистості майбутнього фахівця за вектором формування 